UDC 141.3:2-1

\title{
THE CONCEPTS OF ESOTERICISM AND EXOTERISM IN THE CONTEXT OF RELIGIOUS AND PHILOSOPHICAL DOCTRINES OF THE 20TH CENTURY
}

\author{
(c) Igor M. Grekov
}

\author{
Ryazan State University, Ryazan, Russian Federation \\ science-almanac@mail.ru
}

\begin{abstract}
This article discusses the concepts of esotericism and exoterism in the context of religious and philosophical teachings of the XX century. The author focuses on theosophy of E. Blavatsky, A. Besant, the "living ethics" of the Roerichs, the anthroposophy of R. Steiner, the traditionalism of R. Genon, the doctrine of the "Rose of the World" by D. Andreev, and the Esoteric Christianity of B. Muravyov. Analyzing the works of N. Berdyaev, the author comes to the conclusion that for the thinker the mystical is the esoteric (inner) experience, a state that is practically not transmitted through concepts in contrast to theology, which is exoteric. The dominance of the new religiosity of $\mathrm{N}$. A. Berdyaev connects with the formation of a synthetic religious teaching, the basis of which will be conscious mysticism, mystical realism, the opposite of common sense and justified by reason. gnosis.

Key words: esotericism, mesotericism, exotericism, theosophy, esoteric philosophy, mysticism, tradition,

\section{[И.М. Греков Понятия эзотеризм и экзотеризм в контексте религиозно-философрских учений XX} века]

Рассматриваются понятия эзотеризм и экзотеризм в контексте религиозно-философрских учений XX века. В центре внимания автора - теософия Е. Блаватской, А. Безант, «живая этика» Рерихов, антропософия Р. Штайнера, традиционализм Р. Генона, учение о «Розе Мира» Д. Андреева, а также эзоте-рическое христианство Б. Муравьева. Анализируя работы Н. Бердяева, автор приходит к выводу, что для мыслителя мистическое и есть эзотерическое (внутреннее), переживание, состояние, которое практически не передается с помощью понятий в противовес теология, которая экзотерична Господство новой религиозности Н.А. Бердяев связывает с формированием синтетического религиозного учения, основанием которого станет сознательная мистика, мистический реализм, противоположный здравому смыслу и оправданный разумом.
\end{abstract}

Ключевые слова: эзотеризм, мезотеризм, экзотеризм, теософия, эзотерическая фрилософия, мистицизм, традиция, гнозис.

Igor M. Grekov - Ph.D. in Philosophy, Ryazan State University, Ryazan, Russian Federation.

Греков Игорь Михайлович - кандидат философьских наук, Рязанский государственный университет, 2. Рязань, Российская Федерация.

Helena Petrovna Blavatsky (1831-1891), a religious philosopher, theo-philosopher of the 19th century, had a significant influence on many thinkers of the 20th century, among whom should be named, first of all, Helena Ivanovna Roerich (1879-1955) and Nicholas Roerich (1874-1847). E.I. Roerich writes about H.P. Blavatsky in his letters: "I bow before the great spirit and fiery heart of our compatriot and I know that in future Russia her name will be placed at the proper level of veneration" [15, p. 368].

In this regard, let us turn to the characteristics of esotericism and exoterism given by E.P. Blavatsky in such works as "Isis Unveiled", "The Secret Doctrine", "Commentaries on The Secret Doctrine", "The Key to Theosophy", "In Search of the Occult", "The Science of Life", "Occult or Magic", "Practical occultism", "The Phenomenon of Man" [5-13].

In her work "The Key to Theosophy" H.P. Blavatsky, answering the question about the esotericity of ancient religions, emphasizes: "The best proof of this fact is that every ancient 
religious or, rather, philosophical cult consisted of esoteric or secret teaching and exoteric (for the general public) worship" [6]. In this context, esotericism is the only true secret teaching, the limit of possible human knowledge, guarded by initiates from profanation, "inner beliefs" kept secret. These secrets were guarded by initiates in India, Persia, Central Asia, Egypt, and Ancient Greece. Religious teachings were an external (exoteric) body, a public shell and contained a hidden soul, true (esoteric) knowledge. People were given an external form of philosophical secrets that could not be grasped by physical and chemical processes.

The inner, deep essence of religious and philosophical teachings as an esoteric philosophy is designated by E.P. Blavatsky's "Secret Doctrine", the basis of spiritual life, in the process of comprehending which a person is freed from dogmas, including religious ones: "Esoteric Philosophy never rejected" God in Nature ", just like the Divine, as an absolute and an abstract Entity. She only refuses to recognize the gods, the so-called monotheistic religions, created by man in their own image and likeness, the sacrilegious and sad caricatures of the Ever-Unknowable" [12, p. 24]. The main characteristic feature of esoteric philosophy, according to E.P. Blavatsky, is the identity of her ideas to the foundations of every religion in the history of human development. In this regard, one should distinguish between the orthodoxy of religions as their outer shell and esoteric teachings, their inner meaning.

The concepts of esoteric philosophy and theosophy are considered by E.P. Blavatsky as identical: "Theosophy is the ancient Religion of Wisdom, an esoteric doctrine, once known in all countries claiming to be civilized" [5, p. 240]. Formulating the main ideas of the esoteric teaching (Secret Doctrine), Blavatsky relies on three fundamental tenets: first, there is an Eternal, Omnipresent, Immutable, Infinite Principle, which is impossible to think, and which is inexpressible in words. This is the Eternal Cause, the One, Absolute Reality, preceding the manifested world, the One Absolute Being as the theological Trinity. The first aspect of this unity is the identity of Being and non-Being, the second is the unmanifest Logos, the first cause of the manifested Logos, the third is Spirit-Matter (Life), the fourth is the Cosmic Mind as the Universal Soul, the noumenon of primitive matter. Absolute Being is symbolized as the continuity of Absolute Space and Absolute Movement, represented by Unconditional Consciousness and necessary for the manifestation of the Universe. Secondly, everything in the world is subject to the law of periodicity, according to which appearance and disappearance, ebb and flow, days and nights, sleep and wakefulness, life and death are inevitable. Thirdly, each soul, as the identity of the All-Peaceful Soul and the aspect of the "Unknown Root", wanders in accordance with the law of cycles (incarnations) or necessity (karma).

Annie Besant (1847-1933), following E.P. Blavatsky, in the following way formulates the basic ideas of Theosophy: about a single and unmanifest, eternal, unknowable, real being; about the manifested God: from unity to duality, from duality to triplicity; about the manifestation of intelligent spiritual entities from the Trinity, the leaders of the Cosmos; about man as a threefold being, whose true real "I" is eternal and one with the Universe; about the evolution of man through his incarnations.

Emphasizing the exceptional role of Theosophy in the life of mankind, A. Besant characterizes this teaching as Divine Wisdom given to mankind and proceeding from a single source. Theosophy forms the basis of all religions, dwells in each of them, being the wisdom guarded by the spiritual Teachers of mankind.

Theosophy is considered by A. Besant as an internal (esoteric) doctrine, which includes all religious truths: "it is Esoteric Christianity, as is Esoteric Buddhism, and it belongs equally to every religion, exclusively to none" [2, p. 10], therefore, theosophia is not intended for those who are content with external (exoteric) teachings. 
The teachings of Helena Ivanovna Roerich $(1879$ - 1955) and Nicholas Roerich (1874 1947), followers of E.P. Blavatsky, which received its name "Living Ethics", can also be attributed to the esoteric teachings of the 20th century.

Esoteric teaching is understood by E.I. Roerich, first of all, as knowledge inaccessible to the broad masses: "Esoteric Teaching ceases to be such, since it is written down in an outline or language that is understandable to everyone" [16, p. 150]. In this context, only "enlightened consciousness" can perceive the teaching positioning itself as theosophical and scientific: "Only a truly enlightened mind and heart can understand the purity and beauty of high service to the Common Good, set forth in the Teaching of Living Ethics" [18, p. 351]. And also: "A primitive, uncultured and undisciplined mind cannot grasp and understand the cosmic inclusiveness of the Teaching, coming from ancient times, from the very Sources of the Knowledge of Light" [18, p. 258]. Secrecy and mystery are recognized as the main attributes of this kind of teaching.

Describing "Living Ethics", Agni Yoga, E.I. Roerich notes that it is called upon to approve a new worldview, the significant features of which are: a person's awareness of the consequences of their actions, karmic debts, responsibility for their own actions, striving for unity, fostering a feeling of love for humanity in all forms of its manifestation, expansion of consciousness, friendly cooperation in the family, striving for artistic creativity, expansion of mental horizons, wisdom and worthiness of passing the earthly path, work and improvement for the common good. This new worldview is formed as a result of mastering the "three keys" that are stored in the inner world of a person: "Their names are: LOVE, BEAUTY and KNOWLEDGE" [19]. However, the nature of man is imperfect and people tend to wishful thinking: "We often hear smug exclamations: "I have already changed, I have already succeeded!" The wobbling self, have you examined yourself correctly?" [20]. A well-aimed characterization of the impermanence of the human "I" is not a final judgment on the level of spiritual development of mankind. The Living Ethics, Agni Yoga, which strengthens the psychic energy of people and forms an unbreakable union with Science and Art, is called upon to provide help.

The core of this teaching, according to E.I. Roerich, are the moral foundations of the religions of the world, forming an awareness of their own responsibility and duty in relation to the world, intolerance to all forms of manifestation of lies and hypocrisy. Cultural values, the world of beauty and art contribute to the spiritual purification of a person and improve his manifestations, and creative work is viewed as a constant, intelligent and heartfelt work. This doing is devoid of mechanism and artificial irritation of the centers, because violent exercises develop only "lower psychism", various types of "obsession": "Spirituality is not acquired by mechanical exercises. Mediumship and spirituality are antipodes: enough is said about this in the books of Living Ethics" [16, p. 179].

Living Ethics indicates the direction of the evolution of mankind, in which vitality acquires the status of a necessity in a successful fight against diseases and threats of physical existence. Comprehension of vitality as a manifestation of love and a feeling of beauty in the heart of a person contributes to the service of the common good: "Selflessness, indicated in the Teaching of Ethics, is not a renunciation of self-manifestation, but ardent beautiful courage and daring in the name of the Common Good" [17, p. 165].

The doctrine of the spiritual evolution of mankind, according to E.I. Roerich, should contain both an esoteric part, which is understood as a "secret" transmitted to humanity by the elect, and an exoteric part, given for perception by wide layers of society. Turning to the Theosophical Society (1875 - the year of its creation), which claimed its exclusive authority after the death of E.P. Blavatsky, E.I. Roerich asks the question of the legitimacy of claims to the top leadership in the absence of receiving the "High Teaching" from the Great Teachers of mankind: "The Theosophical Society does not have any data and rights to assert its exclusive authority and lay claim to the Highest leadership. But, of course, we will be told that 
everything they receive is so esoteric that it cannot be given out. But then we ask, why in other Spiritual Centers, along with esoteric messages, are exoteric messages given? Where are their exoteric Teachings?" [18, p. 27].

Rudolf Steiner $(1861-1825)$, who initially fully shared the views of the Theosophical Society, subsequently created his own direction, which was called anthroposophical. The German section of the Theosophical Society was transformed into the Anthroposophical Society, which, in fact, he headed together with Maria von Sievers (1867-1948).

When defining the essence and place of esotericism, esoteric in the life of society, R. Steiner relies on the provisions concerning the development of human cognitive abilities in the spiritual sphere: "In any esoteric teaching, it is about learning how to consider the things around us "[21, p. 6]. Initially, a person saw the world in images, then concepts were given to him, and later he must learn to act in accordance with the understanding of the deep connections in the world between the Microcosm and the Macrocosm. This "higher" view of things is associated with the development of inner contemplation: "In every fragment of the world, the esotericist sees a connection with something in himself. Then the inner relationship is revealed" [21, p. 8]. The development of this kind of consciousness and the ability to such contemplation is facilitated by intensive training, which, according to R. Steiner, was carried out in every religion, at every stage of the historical development of mankind.

R. Steiner connects this training with the identification and development of the inner spiritual abilities of a person to cognize "supersensible worlds" [22] and describes the stages of the educational path in his work: "The Path to Consecration" [23]. The spiritual path requires its preparation, understanding of certain spiritual laws, including the law of karma, considered by R. Steiner as a tool for regulating human activities.

René Guénon (1886 - 1951) was quite critical of the theosophy of H.P. Blavatsky and R. Steiner, noting their unfounded claims to obtain the status of ideological inspirers of synthetic teaching. In his opinion, this theosophy is far from synthesis, moreover, it bears a profane, "external" character. Synthesis, which is the inner unity of existence, is opposed to syncretism, which rests on the periphery, consisting of many disparate elements that are far from the center. The syncretism of theosophy is expressed in the artificial union of contradictory individual facts, closed "atoms", collected by external means. This eclectic teaching can appear as a holistic doctrine only to those who are content with a superficial consideration of ideas. However, a chaotic mixture is collected by the syncretic method around the central idea, and such an idea in Theosophy is the idea of evolution: "... it is by the "syncretic" method that the so-called "Eastern tradition" of Theosophy is created, which in fact has almost nothing Eastern, except for poorly understood and misused terminology ..." [14].

The central concept of the teachings of R. Guénon is the concept of tradition. According to R. Guénon, in the modern world the word "tradition" is used in the meaning of custom, habit, which distorts the meaning of this concept and excludes essential features - the presence of elements of a superhuman order, the transcendence of fundamental principles, the invariability of its main principles, transmission. The idea of the transfer, according to R. Guénon, is an essential moment of tradition. It should be emphasized that we are not talking about any transmission, transmission of the accumulated socio-cultural experience of mankind, but about the transmission of what belongs to the field of the supernatural, metaphysical, esoteric. If tradition leads to the center, to unity, to the point where all traditions are united at one point, then this tradition is in the realm of the esoteric. "If for some reason a certain tradition turns out to be incomplete, then, using the same comparison, we can say that this road does not lead to the center, but is interrupted at some point that clearly enough indicates a transition from the esoteric to the exoteric realm" [14].

In this context, the concepts of esoteric and exoteric are used to denote the inner, central, synthetic and outer, peripheral areas of the tradition. 
The twentieth century proved to be fruitful in terms of the emergence and spread of ideas that were considered esoteric. Among the ideas about a single spiritual and moral foundation of mankind, the root of all religions, the core of morality, are of considerable interest, in our opinion, those that became the content of the book "The Rose of the World" by the Russian thinker, philosopher and mystic - Daniel Andreev (1906 - 1959). The rose of the world and its constituent petals are a symbol of the unity of all religions, each of which reflects its individual character, the uniqueness acquired in the process of evolution, and the universal features inherent in all others.

According to $D$. Andreev, the 20th century differs from all previous ones in its striving for the world. However, the danger to humanity may lie in the fact that this unity will be the result of the activities of forces striving for a world dictatorship, the establishment of total control and violence. The state cannot prevent the implementation of this scenario due to its extraethical nature, therefore, it is necessary to create an instance standing above the World Federation of States, which would be ethical, incorruptible, reject violence and in its activities relied on universal interreligion.

Unlike many esoteric concepts of the 20th century, D. Andreev's doctrine of the Rose of the World contains not only ideas about the inner transformation of a person, a person of a "ennobled image", but also ideas about social transformation. The focus of teaching on solving specific historical problems in the context of the development of social conscience, social compassion and sympathy, practical actions to transform the social body, according to D. Andreev, distinguish the Rose of Peace from all previous religions.

Daniil Andreev was convinced that sooner or later the esoteric (in the context of his work a complex, open only for the elite, incomprehensible, deep in its content) teaching will become accessible: "The atmosphere of the Rose of the World and her teachings will create the mythologeme about culture has become the property of every mind" [1]. According to D. Andreev, being the successor of the spiritual experience of mankind, "The Rose of the World" is a dynamic teaching based on the cathedral mystical mind of mankind.

It should be noted that the idea that the essence of any religion is mysticism is also shared by the Russian religious philosopher N.A. Berdyaev (1874 - 1948). In his work "Mysticism and Religion" [3] N.A. Berdyaev draws attention to the fact that mysticism is identified in everyday consciousness as everything mysterious and even insane, and mystical experience with occult and spiritualistic charlatanism.

Whether mysticism is only a subjective state, hallucination, self-deception or mysticism is an objective state of the nature of every person, the nature of the world, this problem is in the center of N.A. Berdyaev. Mystical experience, according to Berdyaev, is characteristic of all people without exception. However, mysticism is aristocratic, and religion is democratic, social.

According to N.A. Berdyaev: "Mysticism is the overcoming of creation" [4, p. 429]. Mysticism has an objective truth, it is a true element of human and world nature, while mystification is inherent in subjectivism, individual and irrationally arbitrary features.

A person can plunge into the mystical element at certain moments of his life, then he experiences delight, inspiration, ecstasy. In this state, the boundaries of the subject and the object are erased, in this regard: "mysticism can be defined as a state resting on the identity of a subject and an object, as a merger of a human being with universal being, as communication with the world, which does not condition the world in anything" [3]. Such unity, which removes the contradictions between the object and the subject, acquaints a person with the fundamental principle of being. The essence of religious life, according to N.A. Berdyaev, in the performance of the sacrament in which objective reality is revealed: "Religion is mysticism, in which the Logos shone, the insight of the meaning of things began" [3]. In this regard, religion stems from an objective, universal, mystical revelation. 
For a thinker, mystical is an esoteric (internal) experience, a state that is practically not conveyed with the help of concepts, therefore any theology is exoteric: "The concept of God, developed by kataphatic theology, is always exoteric in nature. Christian dogma is only a symbolism of spiritual experience. The objectification of the spirit taking place in it cannot be recognized as the ultimate truth. Mystics go further, but they do not operate with concepts, they resort to symbols and myths to communicate their experience to other people" [4, $p$. 433-434]. The mystics strive to cognize the Absolute, ultimate Mystery, which states the following: "1) from the Divine Nothing, from Gottheit, from Ungrund, God, the Trinity, is realized in eternity, and 2) God, the Trinity, creates the world. This means that in eternity there is a theogonic process, divine birth. This is the inner, esoteric life of the Divine" [4, p. 434]. The dominance of the new religiosity N.A. Berdyaev connects with the formation of a synthetic religious doctrine, the basis of which will be conscious mysticism, mystical realism, opposite to common sense and justified by reason.

A striking phenomenon of esoteric literature of the $X X$ century, in our opinion, is the three-volume work "Gnosis" by Boris Petrovich Muravyov (1890-1966), founder and head of the Center for the Study of Esoteric Christianity (1962, Switzerland, Geneva). This work, translated into Russian in the 90s, was published in our country only once, in 1998. In this study, which structurally consists of three parts, B.P. Muraviev, step by step, following the logic "from simple to complex", introduces the reader to esoteric philosophy, esoteric "science".

The concepts of esotericism, esotericism, esoteric philosophy, esoteric science are used by B.P. Muravyov as synonyms. The essence of the esoteric is in the movement towards universal synthesis, the center, towards the comprehension of the truth, the essence of the only Tradition, existing in various forms in a given cultural and historical context. Various religious forms are necessary to facilitate the understanding of aspects of the single truth, the revelation of the truth by certain groups of people whose goal is to achieve personal salvation. Christianity, according to B.P. Muravyov, on the contrary, addresses all of humanity. Comprehension and initiation into the secret, innermost Divine Wisdom in the 20th century can become more accessible for those who in esotericism explore themselves, learn what they are and what they can become in the process of working on themselves, using introspection - the method of introspection.

Walking the path from the point of mastering exoteric knowledge, bypassing the mesoteric stage, to the point of mastering esoteric knowledge is the life task of a person striving to achieve spiritual growth. This way B.P. Muravyov compares with education, which includes the stages of primary, school (secondary) and higher education. To master esoteric knowledge means to successfully pass all educational stages: exoteric, mesoteric and esoteric.

Esoteric teaching requires "prostate", righteousness, which can be misinterpreted and then a person is trapped in his own illusions about his chosenness and "advancement" along the spiritual path. B. Muravyov characterizes the initial educational stage as uniform, the middle stage as the stage of preliminary specialization (monastic or secular) and the higher stage as the stage of combining types of specialization.

Thus, the esoteric Christianity of B. Muravyov, the theosophy of E. Blavatsky and her followers, the "living ethics" of the Roerichs, the anthroposophy of R. Steiner, the traditionalism of R. Guénon, the doctrine of the "Rose of the World" D. Andreev are teachings in which esotericism and exoterism are considered as forms of knowledge about the sacred: about the Absolute, the Universe, man, as the boundaries of possible human knowledge about the universe (esotericism as the highest limit). 


\section{Лuтература}

1. Андреев Д. Роза Мира [Электронный ресурc]. URL: http://rozamira.nl/lib/ae/rm12.htm\#19 (Дата обращения: 08.06.2020).

2. Безант А. Эзотерическое христианство. Малые мистерии. М.: София, 2008.

3. Бердяев Н.А. Мистика и религия // Новое религиозное сознание и общественность. СПб.: Издание М.В. Пирожкова, 1907. URL: http://www.odinblago.ru/filosofiya/berdyaev/berdyaev_novoe_rel_sozn/02/ (дата обращения: 11.06.2020).

4. Бердяев Н.А. Философия свободного духа. М.: Республика, 1994.

5. Блаватская Е.П. В поисках оккультизма. М.: Сфера, 1996.

6. Блаватская Е.П. Ключ к теософии. М.: Эскимо, 2006 [Электронный ресурс]. URL: https://www.klex.ru/1xg (Дата обращения: 23.05.2020).

7. Блаватская Е.П. Комментарии к «Тайной доктрине». Протоколы ложи Блаватской. М.: Амрита, 2012.

8. Блаватская Е.П. Наука жизни. М.: Сфера, 1999.

9. Блаватская Е.П. Оккультизм или магия. М.: Эскимо, 2006.

10.Блаватская Е.П. Практический оккультизм. М.: АСТ, 2004.

11. Блаватская Е.П. Разоблаченная Изида. Ключ к тайнам древней и современной науки и теософии. Т. I-II. М.: Эскимо-Пресс, 2007.

12. Блаватская Е.П. Тайная Доктрина. В 2 т. М.: Эскимо, 2014.

13. Блаватская Е.П. Феномен человека. М.: Сфера, 2006.

14.Генон P. Очерки о традиции и метафизике [Электронный ресурс]. URL: https://fil.wikireading.ru/51559 (дата обращения: 23.06.2020).

15.Pерих Е.И. Письма. В 9 т. Т. 2 (1934). М.: Международный Центр Рерихов; Благотворительный Фонд им. Е.И. Рерих; Мастер-Банк, 2013.

16. Рерих Е.И. Письма. Т. IV. (1936 г.). М.: Международный Центр Рерихов, 2002.

17.Pepux Е.И. Письма. Т. VII. (1940-1947 г.). М.: Международный Центр Рерихов, 2007.

18. Рерих Е.И. Письма. Том II. (1934 г.). М.: Международный Центр Рерихов, 2000.

19.Pepux Е.И. Три ключа [Электронный ресурс]. - Режим доступа: http://agnivesti.ru/news4357 (дата обращения: 29.05.2020).

20. Рерих Е.И., Рерих Н.К. Агни Йога. Великое наследие (сборник). М.: Издательство ACT, 2013 [Электронный ресурc]. URL: https://books.google.ru (дата обращения: 01.06.2020).

21. Штайнер Р. Основные элементы эзотерики. Калуга: Духовное познание, 1992.

22. Штайнер Р. Познание сверхчувственных миров. М.: Амрита. 2015.

23. Штайнер Р. Путь к посвящению. М.: Амрита-Русь. 2004.

\section{References}

1. Andreyev D. Roza Mira [Rose of the World]. Available at: http://rozamira.nl/lib/ae/rm12.htm\#19 (accessed: 8 June 2020) (in Russian).

2. Bezant A. Ezotericheskoye khristianstvo. Malyye misterii [Esoteric Christianity. Small mysteries]. Moscow: Sofiya. 2008 (in Russian).

3. Berdyayev N.A. Mistika i religiya. Novoye religioznoye soznaniye i obshchestvennost. [Mysticism and religion. New religious consciousness and society]. Saint Petersburg: Izdaniye

M.V.

Pirozhkova,

1907.

Available

at: 
http://www.odinblago.ru/filosofiya/berdyaev/berdyaev_novoe_rel_sozn/02/ (accessed: 11 June 2020) (in Russian).

4. Berdyayev N.A. Filosofiya svobodnogo dukkha [Philosophy of the free spirit]. Moscow: Respublika, 1994 (in Russian).

5. Blavatskaya Ye.P. V poiskakh okkultizma [In search of the occult]. Moscow: Sfera, 1996 (in Russian).

6. Blavatskaya Ye.P. Klyuch k teosofii [The Key to Theosophy]. Moscow: Eskimo. 2006 Available at: https://www.klex.ru/1xg (accessed: 23 May 2020) (in Russian).

7. Blavatskaya Ye.P. Kommentarii k «Taynoy doktrine». Protokoly lozhi Blavatskoy [Commentaries on The Secret Doctrine. Blavatsky Lodge Protocols]. Moscow: Amrita, 2012 (in Russian).

8. Blavatskaya Ye.P. Nauka zhizni [Life Science]. Moscow: Sfera, 1999 (in Russian).

9. Blavatskaya Ye.P. Okkultizm ili magiya [Occult or magic]. Moscow: Eskimo, 2006 (in Russian).

10. Blavatskaya Ye.P. Prakticheskiy okkultizm [Practical occultism]. Moscow: ACT, 2004 (in Russian).

11. Blavatskaya Ye.P. Razoblachennaya Izida. Klyuch k taynam drevney i sovremennoy nauki i teosofii [Isis Unveiled. The key to the secrets of ancient and modern science and theosophy]. V. I-II. Moscow: Eskimo-Press, 2007 (in Russian).

12. Blavatsky Ye.P. Taynaya Doktrina [Secret Doctrine]. In 2 V. Moscow: Eskimo, 2014 (in Russian).

13. Blavatsky Ye.P. Fenomen cheloveka [The human phenomenon]. Moscow: Sfera, 2006.

14. Guénon R. Ocherki o traditsii i metafizike [Essays on tradition and metaphysics]. Available at: https://fil.wikireading.ru/51559 (accessed: 23 June 2020) (in Russian).

15. Roerich E.I. Pisma [Letters]. In 9 V. V. 2 (1934). Moscow: Mezhdunarodnyy Tsentr Rerikhov; Blagotvoritelnyy Fond im. Ye.I. Rerikh. Master-Bank. 2013 (in Russian).

16. Roerich Ye.I. Pisma. [Letters]. V. IV. (1936 g.). Moscow: Mezhdunarodnyy Tsentr Rerikhov, 2002 (in Russian).

17. Roerich Ye.I. Pisma. [Letters]. V. VII. (1940-1947 g.). Moscow: Mezhdunarodnyy Tsentr Rerikhov, 2007 (in Russian).

18. Roerich Ye.I. Pisma [Letters]. V. II. (1934 g.). Moscow: Mezhdunarodnyy Tsentr Rerikhov, 2000 (in Russian).

19. Roerich Ye.I. Tri klyucha [Three keys]. Available at: http://agnivesti.ru/news4357 (accessed: 29 May 2020).

20. Roerich Ye.l., Roerich N.K. Agni Yoga. Velikoye naslediye (sbornik). [Agni Yoga. Great heritage (collection)]. Moscow.: Izdatelstvo AST, 2013 Available at: https://books.google.ru (accessed:01 June 2020) (in Russian).

21. Steiner R. Osnovnyye elementy ezoteriki [Basic elements of esotericism]. Kaluga: Dukhovnoye poznaniye, 1992 (in Russian).

22. Steiner $R$. Poznaniye sverkhchuvstvennykh mirov [Knowledge of supersensible worlds]. Moscow: Amrita. 2015 (in Russian).

23. Steiner R. Put k posvyashcheniyu [The Path to Initiation.]. Moscow: Amrita-Rus. 2004 (in Russian). 